\title{
Drama, Performance and Touch in the Medieval Convent and Beyond
}

\section{Olivia Robinson and Elisabeth Dutton}

\subsection{INTRODUCTION}

We begin by evoking an image that is almost certainly familiar: a depiction of Mary Magdalene encountering the risen Christ, at the moment at which he tells her noli me tangere - conventionally translated today as 'touch me not'. 'Throughout the Middle Ages this moment was repeatedly portrayed,

\footnotetext{
${ }^{1}$ Reimund Bieringer explores the resonances of the Greek and Latin versions of this utterance, and the interpretative difficulties manifested within its long tradition of translation, 'Noli me tangere and the New Testament: An Exegetical Approach', in Noli me tangere. Mary Magdalene: One Person, Many Images. Exhibition in the Maurits Sabbe Library, 23 February-30 April 2006 (Leuven: Maurits Sabbe Library, Faculty of Theology KU Leuven, Peeters, 2006), 13-27.
}

O. Robinson $(\bowtie)$

Université de Fribourg, Fribourg, Switzerland

University of Birmingham, Birmingham, UK

e-mail: olivia.robinson@unifr.ch

E. Dutton

Université de Fribourg, Fribourg, Switzerland

e-mail: elisabeth.dutton@unifr.ch

(C) The Author(s) 2019

D. Carrillo-Rangel et al. (eds.), Touching, Devotional Practices, and

Visionary Experience in the Late Middle Ages, https://doi.org/10.1007/978-3-030-26029-3_3 
in paintings, frescoes, manuscript illustrations, carvings on pillars and doors, and, as we will discuss here, in theatre. One of the most striking aspects shared by almost all the artistic realisations of this moment is a certain ambiguity in the movement of Christ. As he turns to enjoin Mary not to touch him, he stretches out a hand that we can only interpret as repelling because we know the narrative. Faced only with a picture, without text, we might well interpret Christ's hand as reaching to touch Mary, rather than reaching to prohibit touch. The moment here captured could lead to a lover's embrace. ${ }^{2}$ Christ's words, noli me tangere, position him as grammatical object, while also giving him a subject's authority to command: the ambiguity of the gesture depicted allows a possible mutuality, both Mary and Christ at once touching subjects and the objects of each other's touch. ${ }^{3}$

Our second, perhaps less familiar, image is of St Wilgefortis, depicted by Hieronymus Bosch (Fig. 3.1). Wilgefortis is a female saint who grows a miraculous beard when faced with an unwanted marriage to a nonChristian suitor - a beard which instantly puts him off-and is crucified, Christ-like, as a result. The bearded Wilgefortis forms an arresting image of a body 'performing' femininity and masculinity simultaneously: Bosch here realises, unsettlingly, an apparently naturalistic, bearded but nonetheless female face. Wilgefortis's beard, however, also performs or catalyses her shift from 'object' to 'subject' position: she starts as the object of someone else's narrative (her father's, her future husband's), but her beard makes her subject or actor within her own. Her facial hair signals her unwillingness to perform through her body the role of wife, and forms the means by which she instead performs her identity as chaste follower and imitator of Christ, with whom she shares a profoundly ambiguously

\footnotetext{
${ }^{2}$ An image in a fifteenth-century prayer book, in which a Dominican nun embraces and is embraced by the suffering, rather than the resurrected Christ, perhaps realises this potential: the image otherwise recalls noli me tangere iconography - the garden, the kneeling woman, the standing Christ reaching down to her. See Salvador Ryan, 'Christ the Wounded Lover and Affective Piety in Late Medieval Ireland and Beyond', in The Materiality of Devotion in Late Medieval Northern Europe, ed. Henning Laugerud et al. (Dublin: Four Courts Press, 2016), Plate 6.

${ }^{3}$ Barbara Baert explores this profoundly complex moment in "'An Odour. A Taste. A Touch. Impossible to Describe." Noli me tangere and the Senses', in Religion and the Senses in Early Modern Europe, ed. Wietse de Boer and Christine Göttler (Leiden: Brill, 2013), $111-151$.
} 


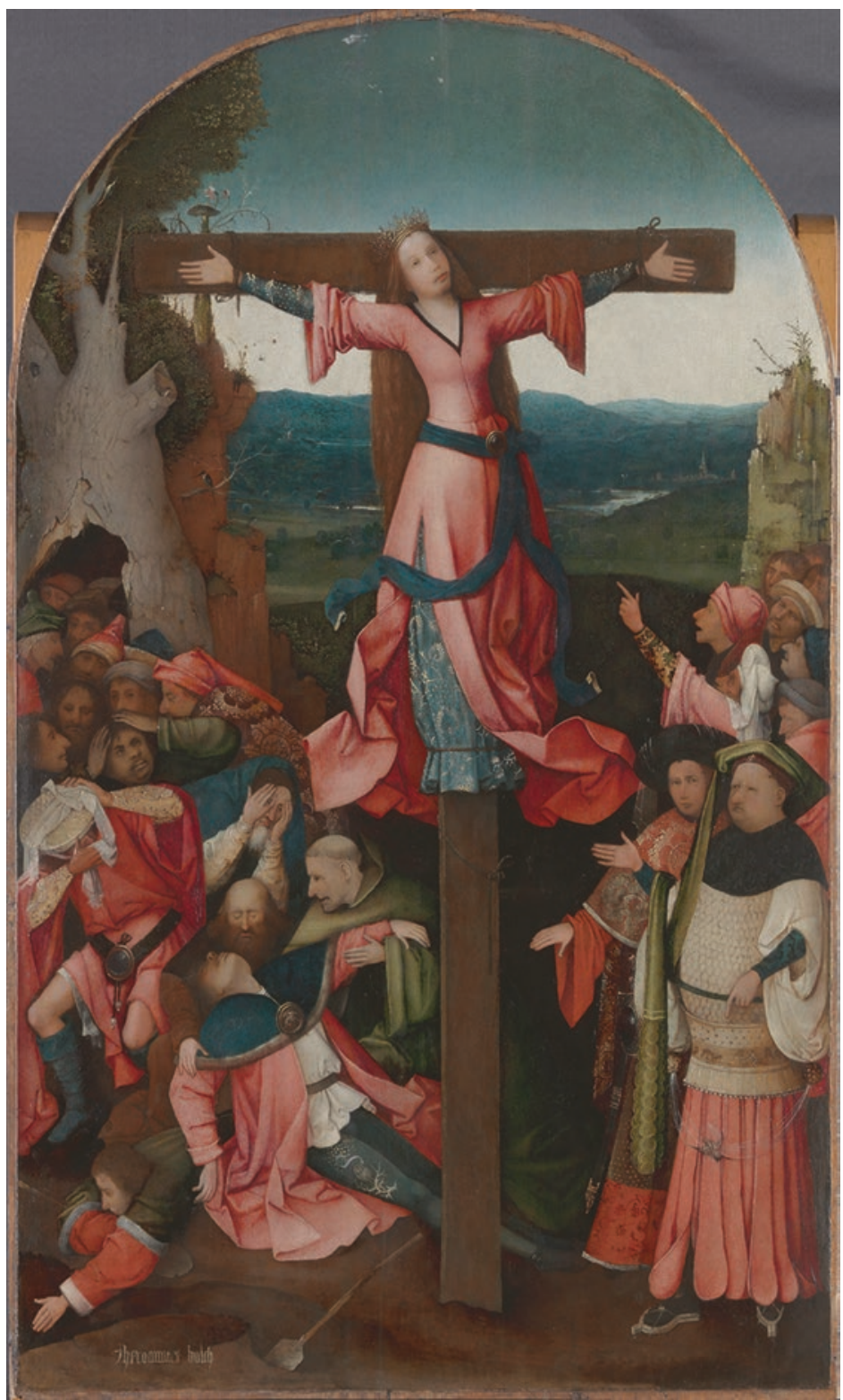

Fig. 3.1 Triptych of St Wilgefortis, central panel, $104 \times 119 \mathrm{~cm}$, inv 76109 . (C) Archivio fotografico G.A.VE su concessione del Ministero dei beni e delle attività culturali. Gallerie dell'Accademia di Venezia 
pluri-gendered body on the cross. ${ }^{4}$ The beard gives Wilgefortis the authority not to be touched by her suitor, and the result is that she is crucified like Christ: on the cross she is both object, acted on by political rulers who inflict pain and gazed upon by spectators, and subject, for she experiences the suffering she has chosen, and that suffering is given authority by identifying her with Christ.

In exploring touch as a phenomenon within medieval convent theatre, we consider the ambiguity of the performer's role-both object of a spectator's gaze, and participating, sensory subject. The conviction underlying this approach is that medieval convent plays most particularly were performed for the spiritual benefit of the players at least as much as the audience. Inevitably, the performers' spiritual experience was created through the senses, including touch-touching, and being touched by, other performers, or apparel, or props. Medieval theatre in all its forms offered rich multisensory experiences to its audiences, and recent research in the field has explored subjective and sensory experiences, both bodily and cognitive, in relation to spectatorship. ${ }^{5}$ We focus here on the player, rather than the spectator: instead of exploring the effects of witnessing touch onstage, or, indeed, of touch as part of an audience's sensory encounter with a play, we consider the operation of the potentially myriad tactile experiences of individual performers, and between performers, in the course of a medieval convent performance. ${ }^{6}$ Critten and Kern-Stähler emphasise that a

${ }^{4}$ For Christ's pluri-gendered body, see Caroline Walker Bynum's seminal article, 'The Body of Christ in the Later Middle Ages: A Reply to Leo Steinberg', Renaissance Quarterly 39 (1986): 399-439.

${ }^{5}$ For example, John J. McGavin and Greg Walker, Imagining Spectatorship from the Mysteries to the Shakespearean Stage (Oxford: Oxford University Press, 2016). Critten and Kern-Stähler offer a discussion of the olfactory properties of the York Corpus Christi plays: Rory Critten and Annette Kern-Stähler, 'Smell in the York Corpus Christi Plays', in The Five Senses in Medieval and Early Modern England, ed. Annette Kern-Stähler, Beatrix Busse, and Wietse de Boer (Leiden: Brill, 2016), 239-268. Farah Karim-Cooper discusses sensory perception and spectatorship in relation to the Elizabethan playhouses, 'The Sensory Body in Shakespeare's Theatres', in The Five Senses, ed. Annette Kern-Stähler, Beatrix Busse and Wietse de Boer, 269-285.

${ }^{6}$ Claire Sponsler underlines the methodological necessity of attending to performers' and spectators' bodily experiences, 'From Archive to Repertoire: The Disguising at Hertford and Performing Practices', in Medieval Theatre Performance, ed. Phillip Butterworth and Katie Normington (Cambridge: D. S. Brewer, 2017), 33. Robinson sketches out some initial thoughts on how medieval performers' embodied experiences might be apprehended: Olivia Robinson, 'Performance-Based Research in the Medieval Convent', European Medieval Drama 21 (2018 for 2017): 21-41. 
critical analysis of potential sensory perception within medieval theatre must always be 'comparative and speculative... [with] a directorial eye... trained on the play-text's realisable potential'. ' While the 'directorial eye' is an anachronistic concept in relation to medieval theatre, we agree that medieval plays cannot be appreciated fully unless attention is paid to the material realisation of their potential: they are scripts requiring performance, and readers must at least imagine or 'direct' them in their heads. We too use play-texts, and written traces of performance of other kinds, comparatively and speculatively, alongside imaginative engagement with the bodily, sensory perceptions engendered by doing theatre within the medieval convent. We add insights suggested by our own contemporary performances of medieval theatre, drawing both on our own bodily experiences and those described in post-performance interviews by the actors with whom we have worked. ${ }^{8}$ Acknowledging the speculative nature of our interpretations, given the inherent difficulty of discussing historically remote subjective experiences, we will nonetheless consider evidence concerning tactile theatrical practice.

Imagining the different kinds of touch which medieval convent theatre necessitates raises a series of questions relating in particular to performers' subjective experience of playmaking, their awareness and manipulation of their own body onstage, as well as audience response to their appearance, movements and interactions. Theatrical attire, ${ }^{9}$ for example, routinely touches bodies for the full duration of a performance: in what ways might this kind of touch affect an enclosed player? The integration of relics, liturgical accoutrements and other ecclesiastical 'props' or vestments into medieval convent performances also raises questions that relate to touch, for touching such objects was often otherwise restricted to a very few, on

${ }^{7}$ Critten and Kern-Stähler, 'Smell', 244.

${ }^{8}$ Jo Day cautions: 'It is crucial, of course, to recognize that all individuals exist in distinct historical and cultural contexts, the confines of which cannot be conveniently overlooked to reembody the past. However, through combining... informed contextual information with the opportunities provided by a shared sensing body, it is possible to formulate new ideas about past experiences of material culture and place'. 'Making Sense of the Past', in Making Senses of the Past: Toward a Sensory Archaeology, ed. Jo Day (Illinois: Southern Illinois Press, 2013), 6 .

${ }^{9}$ Butterworth argues that it is important to avoid the term 'costume' and other contemporary theatrical terms (such as 'actor') where possible, since they 'run the risk of imposing modern theatrical consciousness on medieval conditions'. Phillip Butterworth, Staging Convention in Medieval English Theatre (Cambridge: Cambridge University Press, 2014), 1. We use the terms 'player', 'performer' and 'participant' rather than 'actor' within this chapter. 
very few occasions. How are holy objects held and manipulated onstage by players, and how might the feeling of touching them affect a performer? What is the effect of moments at which participants are led to touch one another within the narratives of convent plays? These questions pertain to 'literal' or physical acts of touching: placing the hands on an object, feeling a wig against the skin, touching another performer's body with one's own.

Understanding 'touch' more metaphorically in relation to medieval theatre raises a further area of enquiry relating to subjective experience and performance. Medieval theatrical convention understood the player and the character presented by the player as always separate, never fully identified with each other, even for the duration of a play. ${ }^{10}$ Medieval performance is not an attempt to 'become' someone other than oneself, but rather a space in which performer and character co-exist, and therefore a space in which they might, metaphorically, be said to touch one another. Touch depends on distinction as well as proximity. What effects might this kind of conceptual 'touching' have produced and how is it described in surviving convent scripts? These are questions that are, in varying degree, relevant to many medieval plays and the performers who took part in them. We here focus on traces of theatrical activity within female monastic environments, at least some of the participants in which were, therefore, female; thus we investigate the interrelationships between medieval religious theatre and touch through the very particular lens of the theatrical experiences of medieval women religious. ${ }^{11}$ From the performance of male bodies to the handling of sacred or liturgical vessels, convent theatre brought nuns into contact with a range of objects and roles that their dayto-day lives precluded, and touch was often a core medium for this contact. The very particular (and understudied) phenomenon of convent theatre therefore involved its participants in a peculiarly rich range of tactile experiences, and we suggest that attending to these experiences is crucial if we are to understand the ways in which theatrical experiences functioned within the lives of enclosed women religious.

\footnotetext{
${ }^{10}$ Meg Twycross and Sarah Carpenter, Masks and Masking in Medieval and Early Tudor England (Aldershot: Ashgate, 2002), 9-10; Butterworth, Staging, e.g., 94-97 or 112-113; Sarah Brazil, 'Forms of Pretence in Pre-modern Drama: From the Visitatio Sepulchri to Hamlet, European Medieval Drama 20 (2016): 181-201.

${ }^{11}$ Our data are in part drawn from our FNS-funded project Medieval Convent Drama, accessed February 16, 2018 (FNS Grant No. 100015_165887), http://www. medievalconventdrama.org. We thank our co-researchers, Aurélie Blanc and Matthew Cheung-Salisbury, for their insights during the writing of this chapter.
} 


\subsection{Touching Apparel: Bearded Ladies}

Wilgefortis could preserve her chastity by growing a beard because the beard in the middle ages brought with it powerful socio-cultural significations: beards, in medieval medical thinking, served as a counterpart to menstrual blood-both were thought to be gendered processes by which non-necessary bodily substances were purged from the body; and the beard was understood medically, ecclesiastically and culturally as a core marker of lay masculinity and of male heterosexual virility. ${ }^{12}$ Wilgefortis's miraculous beard, like a prosthetic stage beard on a young boy or a woman, presents a visual challenge to this: 'Although the stage may share with real life views on correct civility, appropriate gender behaviour, physiological mechanisms, it is also a citation-a quotation of these views and behaviours, negotiating them, sometimes contesting them. [...] The stage may have the effect of making strange that which in another context seems normal, proper. In this way, the scripting of particular bodies may put pressure on culturally circulated ideas about... particular bodies. ${ }^{13}$ In Wilgefortis's life, and, we will argue, in convent theatrical performance, that appropriate gender behaviour, those appropriate physiological mechanisms, can be consciously subverted and knowingly parodied: the beard and all it connotes can be placed upon the body of a woman.

In 2014, Nùria Jornet-Benito published parts of the 1389-1461 sacristy inventories from the Clarissan convent of Sant Antoni and Santa Clara in Barcelona. The inventories record a rich collection of apparel and decorative articles, amongst which, repeatedly mentioned, are false beards ${ }^{14}$ :

Item en la caxa qui està en la volta. Primerament un sobrasel, e una cortina gran. Item mes $\mathrm{C}$ neules entre blanques e pintades, e XVII diademas. Item VI barbes, e VI caballeres de canyem, e una barba negra. ${ }^{15}$

${ }^{12}$ Joan Cadden, The Meanings of Sex Difference in the Middle Ages (Cambridge: Cambridge University Press, 1993), 181-183.

${ }^{13}$ Simon Shepherd, Theatre, Body and Pleasure (London and New York: Routledge, 2006), 36.

${ }^{14}$ Nùria Jornet Benito, 'Un Monestir a la Cruilla: Els Inventaris de Sagristia del Monastir de Sant Antoni i Santa Clara de Barcelona (1389-1461)', Anuario de Estudios Medievales 44 (2014): 277-308.

${ }^{15}$ Arxiu del Monestir de Sant Benet de Montserrat/Fons del Monestir de Santa Clara de Barcelona (AMSBM/MSCB), Sacristy Inventory 1421, vol. 31, núm. 6, fol. 6 v. Our thanks to Nùria Jornet for sharing this material with us, and to David Carrillo-Rangel for its English translation. 
(Item in the box in the vault. Firstly, a canopy [?] and a big curtain. Item one hundred neules, some of them white and some painted, and seventeen crowns. Item six beards and six wigs made of hemp and a black beard.)

La caxa qui és sota la volta: Primo VIIII ${ }^{\circ}$ caballeras, e VII barbes, e XVIIII diademas. Item $\mathrm{C}$ e vint neulas. ${ }^{16}$

(The box under the vault. Firstly, nine wigs and seven beards and nineteen crowns. Item one hundred and twenty neulas.)

Initially, Jornet-Benito speculated that these beards and wigs, as well as the other wigs, garments, elaborate jewellery and false wings mentioned elsewhere in the inventories, might have been employed to decorate statues for use in particular liturgical rituals. More extensive research, however, prompted her to consider that the inventories may preserve evidence of theatrical activity - that the garments were worn by human performers. ${ }^{17}$ Particularly significant is the mention of neulas, cylindrical wafers or pendants that were suspended in churches to count down the days of Lent or the days between Christmas and Epiphany; they were also used in elaborate theatrical ceremonies hosted by parish and monastic churches and cathedrals on other feast days. The neulas rained down, with flowers, and to the accompaniment of incense, to represent the Holy Spirit descending to the apostles at the feast of Pentecost, and Christ's journey heavenwards on Ascension Day. ${ }^{18}$ The mention of neulas within inventory entries also featuring beards and wigs has suggested to Jornet-Benito that the convent of Santa Clara may well have been hosting similar dramatic ceremonies, and that the performers in these ceremonies, therefore, may have been nuns, either exclusively or alongside male clergy. ${ }^{19}$

Our own research into theatre within medieval women's houses in England, Northern France and Burgundy is certainly revealing a wide range of inventive and complex religious theatre and performative ritual, in the composition, copying and performance of which sisters were often fully involved, sometimes, but not always, with male clergy. ${ }^{20}$ The Barking

${ }^{16}$ AMSBM/MSCB, Sacristy Inventory 1437, vol. 31, núm. 8, fol. 9 v.

${ }^{17}$ Nùria Jornet Benito, 'Practices, Objects and Spaces. Some Notes about Liturgy and Paraliturgy at the monastery of S. Antoni i S. Clara of Barcelona' (paper, Lo Spazio nei Monasteri Femminili Medievali, University of Padua, Italy, October 20-21, 2017).

${ }^{18}$ Jornet-Benito, private communication, March 3, 2017; March 8, 2018 and 'Practices'.

${ }^{19}$ Jornet-Benito, private communication, March 3, 2017; March 8, 2018 and 'Practices'.

${ }^{20} \mathrm{We}$ here discuss pieces of Biblically inspired theatre alongside what is often, though increasingly controversially, termed 'liturgical drama': performative rituals embedded within 
Abbey Elevatio and Visitatio Sepulchri performances, for example, were enacted in the conventual church of this women's Benedictine house during Matins on Easter day, featured a mixed group of participants comprising clergy and nuns, and included a lay audience. ${ }^{21}$ In the six surviving vernacular plays from a Carmelite convent in late medieval Huy, sisters would almost certainly have performed male as well as female roles: the plays are unlikely to have been tied to a particular liturgical ritual or space, and the scripts do not signal the participation of clergy, or a specific audience. $^{22}$ Our discussions with contemporary sisters in two Discalced Carmels $^{23}$ have revealed the importance of theatre as an enclosed recreational activity within the Carmelite order to this day: to the amusement of their co-performers and audience, some sisters perform cross-dressed as men, using home-made false beards and wigs fashioned out of household string or wool alongside borrowed men's clothing. These contemporary convent performances cannot, of course, be simply equated with those of medieval nuns, but they can provide an inside perspective on the theatrical practices of enclosed women that prompts us to consider medieval convent performances as potentially more parodic, inventive and transgressive than might otherwise have been imagined. It does not seem to us unlikely that the beards listed in the Santa Clara inventories could have been destined for human performers, nor that at least some of those performers may have been sisters within the convent.

(often redeploying and augmenting the music and language of) liturgical worship, which were widespread within many ecclesiastical institutions across medieval Europe. We feel that the power of such events is found precisely at the intersection between performance or participatory embodiment and formalised rite or worship.

${ }^{21}$ The Barking Abbey Easter ceremonies survive in the house's Ordinale and Customary, Oxford, University College MS, 169, a fifteenth-century manuscript. The performances, however, date to the fourteenth century. We cite from Karl Young, ed., The Drama of the Medieval Church, 2 vols (Oxford: Clarendon Press, 1933). Young separates the two ceremonies; however, the manuscript presents them as sequential.

${ }^{22}$ Five of the Huy Carmelites' plays, all copied in the late fifteenth century, can be found in Gustave Cohen, ed., Mystères et Moralités du ms. 617 de Chantilly (Paris: Droz, 1920). The sixth (which survives in a different, seventeenth-century manuscript, Liège, Arch. État, Fonds DBH doc. 386bis) has not been fully edited. Aurélie Blanc and Olivia Robinson discuss this play: 'The Huy Nativity from the Seventeenth to the Twenty-First Century: Translation, Playback and Pray-back', Medieval English Theatre 40 (2018): 66-97.

${ }^{23}$ OLV ten Troost (Vilvoorde, Belgium) and Le Pâquier (Fribourg, Switzerland). We are grateful to the sisters of both houses for generously welcoming us into their convents, and for taking the time to discuss their recreational theatre with us. 
The use of custom-made articles such as false beards and wigs in medieval theatrical activity is well documented. ${ }^{24}$ The Records of Early English Drama presents a range of evidence relating to performances in medieval England, in both secular and formally religious settings: records are often of financial outlay for the creation or upkeep of particular garments or objects. In 1417-1418 the Wells Cathedral communar's account rolls show that sixteen pence was spent 'pro tinctione I toge Sancti Saluatoris pro ludo in Ebdomada Paschatis \& pro ij barbis pro ij palmerijs' (for the dying of one robe of the Holy Saviour for the play in Easter week and for two beards for two pilgrims). ${ }^{25}$ The following year, the cathedral spent eight shillings six pence 'in I magna pecia de Bokeram blodio pro iij Mantellis pro iij Marijs ad pascha ad Matutinatas' (on one large piece of blue buckram for three mantles for the three Marys at Easter at matins), ${ }^{26}$ while in 1470-1471 it bought 'ij libris de canabo pro crinalibus fiendis ad iij marias ludentes nocte pasche' (two pounds of hemp for making wigs for the three Marys playing on the night of Easter) for six pence, while 'iij quoyfes empties ad dictas iij marias' ('three coifs bought for the said three Marys') cost another three pence. ${ }^{27}$ In Tewksbury, the parish church of St Mary the Virgin's Churchwarden's accounts for 15841585 list the church's 'players Apparrell', including 'iiij capes of green sylke' and 'viij heades of heare for the apostles and .x. beardes' ${ }^{28}$

Clearly, medieval theatrical attire, wigs and beards were designed with attention to the visual significance their colours, shapes and textures carried for spectators. Butterworth demonstrates that matching beards, masks and wigs were used to construct 'groups of personages [characters] such as apostles, pilgrims, good and bad souls'-and he uses this fact to underline the profoundly and designedly non-naturalistic aesthetic of medieval theatrical performance. ${ }^{29}$ Twycross and Carpenter likewise draw

\footnotetext{
${ }^{24}$ For a meticulous and detailed discussion of medieval masking, including the raw materials, fabrication, maintenance, and use of full or partial face-masks, associated wigs, beards and many other coverings in theatrical performance and game, see Twycross and Carpenter, Masks.

${ }^{25}$ REED Somerset, 243 (original entry) and 834 (translation). All subsequent citations from $R E E D$ volumes will be given in this format. We use REED's own translations for Latin material.

${ }^{26}$ REED Somerset, $243,835$.

${ }^{27}$ REED Somerset, $248,838$.

${ }^{28}$ REED Cumberland/Westmorland, Gloucestershire, 337.

${ }^{29}$ Butterworth, Staging, 113-117.
} 
attention to a persistent non-naturalistic, aesthetic and symbolic convention which associated long hair, achieved through wigs, with the performance (by male performers) of particular virtuous (male) biblical characters: 'It... appears to have been a recognised convention on the stage, as in visual art, for virtuous biblical characters to have been distinguished from contemporary figures by long hair. [...] The short male hairstyles during most of the fifteenth century would make wigs a necessary item of costume for actors playing Apostles or Angels ${ }^{30}$ — certainly the false beards and wigs listed by REED were intended for male performers. However, convent theatre, it seems, may have brought female performers into contact with these objects. Beards and wigs worn by sisters playing male roles within convent theatre must have offered a tactile experience that was both unhabitual and insistent. ${ }^{31}$

Writing of the cross-dressing of boys and young men as women which was standard on the Elizabethan and Jacobean public stage, and common (although not universal) within public performances during the Middle Ages too, Andrew McRae notes that 'while we might assume that this must generally have been accepted by audiences as a basic condition of theatrical personation, it would be a mistake to assume that such performances were universally unproblematic. [...] It is fair to assume that the gap between performer and performance was always at least a potential source of interest or friction.' 32 'Friction' is a tactile metaphor: while McRae's formulation here suggests a socio-cultural phenomenon felt principally by the spectator of a cross-dressed player, 'friction' might also be understood literally, as a bodily phenomenon experienced by performers in relation to their attire. Liturgical drama sometimes, like the playhouse

\footnotetext{
${ }^{30}$ Twycross and Carpenter, Masks, 333.

${ }^{31}$ Twycross and Carpenter discuss the different materials which could be used for false beard-making, and which might provoke varying degrees of discomfort against the skin, Masks, 321-333. Hemp fibre, the material used for the wigs, and possibly the beards too, in the 1421 entry at Sta Clara, and for the wigs at Wells, would presumably have made scratchy, comparatively heavy articles.

${ }^{32}$ Andrew McRae, Renaissance Drama (London: Berg, 2003), 33-34. For medieval theatrical cross-dressing, see Robert Clark and Clare Sponsler, 'Queer Play: The Cultural Work of Crossdressing on the Medieval Stage', New Literary History 28 (1997): 319-344, which does not discuss convent theatre. For a more contextual approach, see Katie Normington, 'Player Transformation: The Role of Clothing and Disguise', in Medieval Theatre Performance, 89-90, and on twentieth-century practice-based experiments with male actors playing female roles, Meg Twycross, 'Transvestism in the Mystery Plays', Medieval English Theatre 5 (1983): 123-180.
} 
drama, requires male performers to present female figures. Surviving Visitatio Sepulchri scripts from male monasteries or cathedrals often state explicitly that monks or clergy shall present the three Marys-for example at Fleury 'three brethren, prepared and vested in imitation of the three Marys'. ${ }^{33}$ The vesting and imitation may, however, in many cases have reinforced the male gender of the participants, through Latin language, clerical vestments and liturgical objects used as props. Intriguingly, though, at Wells Cathedral in the fifteenth century it seems the Marys were crossdressed in hemp wigs, and custom-produced mantles and coifs (see above $\mathrm{p}$ XX). These were probably adult male clerics, though they may have been choirboys from the Cathedral School, ${ }^{34}$ in which case the situation would have been more analogous to the boy players representing women in professional theatre. Whether boys or adult men, the Wells three Marys would have experienced physical sensations associated with wearing long, female hair.

Convent theatre, it seems, sometimes required female performers to present male figures. The touch of a false beard against a female face might, we would suggest, produce both kinds of 'friction'. It is about more than an object simply adhering to a performer's body for the duration of a play, for 'the body is not just an assembly of bone and muscle, sinew and viscera. It is a site of sensation where emotion and intellect meet the natural flesh. ${ }^{35}$ A false beard allows the female wearer to feel her body 'signifying' outwardly both male and female, but this is not the same as feeling like a man, since beards come from within the male body: throughout the performance, the performer's internal experience is of course still that of the female body, though juxtaposed with the external touch of the conspicuously male beard on the face. A sister wearing a beard would certainly not have looked, or more importantly here, felt, 'like a man'. Rather, the 'friction' of the beard during performance might trigger something more complex: an acute sensory awareness of the bodily, but culturally inflected or culturally explained attributes of masculinity and the constructed-ness of their social significations.

\footnotetext{
33 'tres fratres praeparati et vestiti in similitudinem trium Marium'. From the Fleury playbook: David Bevington, ed. and trans., Medieval Drama (Boston: Houghton Mifflin, 1975), 39.

${ }^{34}$ For Wells and its schools, see REED Somerset, 464-465.

${ }^{35}$ Monica H. Green, 'Introduction', in A Cultural History of the Body in the Medieval Age, ed. Linda Kalof (New York and Oxford: Berg, 2010), 10.
} 


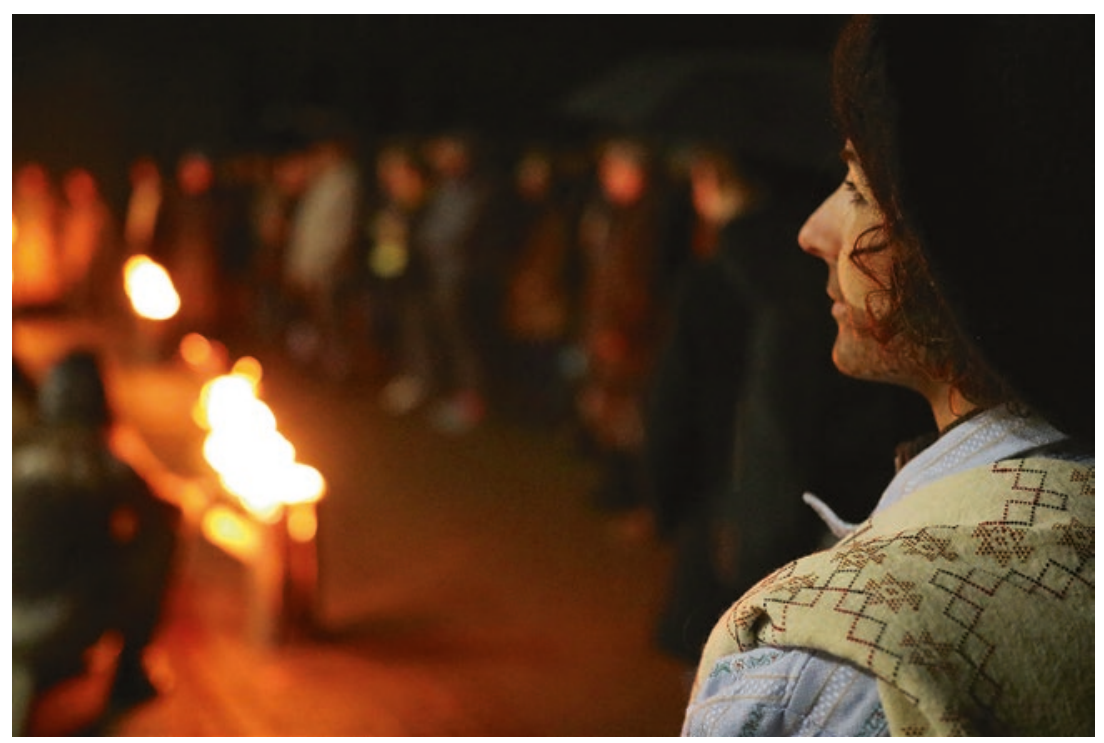

Fig. 3.2 Image of 2017 Fribourg performance of Huy Nativity play, showing female performer playing Joseph in a drawn-on beard. Photo: (c) Alexander Brodard

A similar impulse perhaps lay behind the desire to experiment with beardedness which some of our own performers demonstrated. In our December 2017 all-female performances of the Huy Nativity and Purification plays, our Joseph spontaneously decided to wear a false beard (Fig. 3.2), which she carefully drew on with dark makeup. She applied the beard at home, before coming to the performance venue for our opening night, walking through a busy town centre with it on. She talked afterwards about her interest in bystanders' (and her own daughters') shocked reactions to the beard: for her, provoking these responses was a humorous means to interrogate the socially constructed significations of a physical characteristic usually coded 'male', and to challenge binary thinking about gendered bodies. ${ }^{36}$ Her beard-wearing was, however, very well-received by her fellow-performers once she reached the convent where we were performing. It was also infectious: once she had arrived, other members of the group who were playing male roles immediately began experimenting

${ }^{36}$ DLL (female participant, Joseph) interview with Liv Robinson, December 16, 2017, and post-show conversations. 
enthusiastically together with applying their own beards, and one did in fact play in a beard spontaneously drawn on amid much hilarity in the convent bathroom, using her own eyeliner and with help from a fellowparticipant. Beards, for these performers, perhaps became a way to signal-in part through shared laughter provoked by the dissonance between their drawn-on facial hair and clearly felt feminine bodies - their 'special' status, during the performance, as women playing men in the heightened context of an all-female conventual space and a female-authored, sacred play.

\subsection{Noli Me Tangere: On Not Touching}

Modern lay performers also responded strongly to religious objects that were props in our experimental stagings of medieval convent plays, leading us to speculate about the effects which this kind of tactile experience may have had on the medieval nuns who performed in this theatre. After our recent experimental staging of the Barking Abbey Elevatio and Visitatio Sepulchri ceremonies, one male participant discussed at length the particular effects which holding and manipulating an incense-filled censer produced on him: these included a sensation of pressure to ensure the correct 'swing' (and thus flow of smoke), but also a heady and exciting mixture of memory, familiarity and strangeness triggered by physical proximity to the incense, and the unaccustomed transgression inherent in 'illegally' wearing a priest's vestments and using a censer:

There's a sense of slight subversion, even a bit of a forbidden! [sic.] Because we are not church people, but we wear those [items]... there is a sense of transgression and at the same time of inclusion. It's a very intertwined mix of conflicting feelings... I would get... very dizzy with the smoke... but it contributes totally to the atmosphere of course, with that scent, that mystical odour that you're not used to. And that triggers many memories of previous masses. ${ }^{37}$

Liturgical Visitatio scripts from varying times and places, and from both men's and women's houses, insist on the liturgical objects, and the priestly authority, that represent Christ within the church. ${ }^{38}$ The tenth-century

${ }^{37} \mathrm{~GB}$ (Deacon/Angel), interview with Liv Robinson, April 12, 2018.

${ }^{38} \mathrm{We}$ are particularly grateful to Sarah Brazil, with whom we have had many discussions of this and other aspects of the Visitatio Sepulchri tradition, and whose generosity in sharing her 
Regularis Concordia of St Ethelwold describes the construction of 'a likeness of the sepulchre' by the stretching of a curtain around part of the altar ('Sit autem in una parte altaris... quaedam assimilatio sepulchri, velamenque quoddam in gyro tensum') and the laying inside this 'sepulchre' of the cross, 'as if the body of our Lord Jesus Christ has been buried' ('depositaque cruce, ac si Domini nostri Jhesu Christi corpore sepulto'). ${ }^{39}$ In the later Barking Elevatio, Christ's resurrection is declared by the Priest-Christus resurgens — as he lifts the Lord's body from the sepulchre, 'enclosed in crystal' ('tenendo Corpus Dominicum in manibus suis inclusum cristallo') - evidently the host in a glass monstrance. ${ }^{40}$ In the Visitatio ceremony enacted at Wilton Abbey (like Barking, a wealthy, English Benedictine women's house) the sisters performing the three Marys held thuribles with incense ('turibula cum incensu') in their hands. ${ }^{41}$ However, importantly, thuribles were liturgical items reserved for priestly manipulation, and would not have been habitually touched or held by nuns, so the sisters' participation in the Visitatio here provides them with an opportunity to interact in a tactile way with sacred objects usually only experienced sensorially through sight and smell.

The significance of the thurible and incense is double: at the narrative level, it represents the box of ointment with which the Marys plan to anoint Jesus's body. However, at an extra-diegetic level it connotes sacerdotal power and privilege, and its touch against the hands might remind participants of both of these 'layers', their representation of the three women at the tomb rendering them almost priest-like. For these performers, then, the experience might well have been something more akin to the pleasurable strangeness that our non-priestly participant felt in holding a censer. It is highly suggestive that this tactile experience should come within the episode of the Visitatio, for it is during the scriptural narrative of the visit to the tomb that the risen Christ tells Mary Magdalene not to

ideas and her work-in-progress on Visitatio texts and performers has enriched our thinking enormously.

${ }^{39}$ Bevington, Drama, 16.

${ }^{40}$ Young, Drama, I, 166.

${ }^{41}$ For the Wilton Visitatio, see Susan Rankin, 'A New English Source of the Visitatio Sepulchri, Journal of the Plainsong and Mediaeval Music Society 4 (1981): 1-10. For the Wilton Visitatio manuscript, see Alison Altstatt, 'Re-membering the Wilton Processional', Notes 72 (2016): 690-732. 
touch him. In John's Gospel, ${ }^{42}$ as Christ chooses to appear to Mary Magdalene first, her relationship with Christ appears privileged; as first witnesses to Christ's Resurrection, the Marys are given a position unusual for women, whose testimony was held to be inferior to a man's in Jewish law; ${ }^{43}$ at the same time, Mary Magdalene is forbidden to touch Christ, even though Christ later actively encourages Thomas to touch his risen body. ${ }^{44}$ The Marys holding thuribles enact a tactile transgression of the noli me tangere injunction that, interestingly, is omitted in Wilton's Visitatio: in Wilton Mary Magdalene is 'touched' by Christ-or rather, oddly, struck over the head with a weapon ('percutiet caput eius spiculo') by an Angel who stands for Christ. ${ }^{45}$

Throughout this chapter, we have suggested that performance of medieval convent theatre entails particular bodily experiences that must have contributed to the understanding of the performer, in a different way to reading about, imagining or meditating on the scenes performed. Such sensory moments resonated beyond the moment of performance. The Barking Abbey Visitatio is preceded by a choreographed sequence of largely silent action that marks out the three sisters who will represent Mary Magdalene, Mary Salomé and Mary Jacob:

procedant tres sorores a Domina Abbatissa preelecte, et nigris vestibus in capella Beate Marie Magdalenee exute, nitidissimis superpellicijs induantur, niueis velis a Domina Abbatissa capitibus earum superpositis. Sic igitur preparate et imn manibus ampullas tenentes argenteas dicant Confiteor... ad abbatissam

(three sisters, selected earlier by the Lady Abbess, come forward and, having removed their black garments in the chapel of the Blessed Mary Magdalene, they are dressed in most beautiful surplices, snow-white veils having been placed on their heads by the Lady Abbess. Having thus prepared and holding vases of silver in their hands, they say Confiteor... to the Abbess. ${ }^{46}$

${ }^{42}$ All of the gospels record the Marys visiting the tomb, but only John narrates Mary Magdalene's conversation with Christ and his words noli me tangere (John 20:17). On interpreting these words, see Baert, 'An Odour', 113-116 and Bieringer, 'Noli me tangere'.

${ }^{43}$ See the entry for 'Witness' in Encyclopaedia Judaica, accessed May 29, 2018, http:// www.jewishvirtuallibrary.org/witness.

${ }^{44}$ John 20:27.

${ }^{45}$ Rankin, 'New English Source', 10.

${ }^{46}$ Young, Drama, I, 381, trans. Aurélie Blanc. Dunbar H. Ogden, The Staging of Drama in the Medieval Church (Newark: University of Delaware Press; London: Associated 
The effects and purposes of this ceremony are ambiguous, to say the least. The chosen sisters are first reclothed, the usual black Benedictine habit and veil replaced with white surplice and white veil. The veils are 'placed on their heads by the Lady Abbess', perhaps in the Mary Magdalene chapel: both action and location are prescribed. This moment is tactile: the sisters submit themselves to the repeated touch of their Abbess's hands on their heads. Habitual clothing-indeed, monastic habit—is systematically unpinned, unfastened and lifted away, before being replaced with different garments. ${ }^{47}$ The importance of this, we suggest, might be as much to do with performers' tactile perception of the process of changing their attire as it is to do with how those performers then appear visually, striking though the effect of white veils and surplices undoubtedly is for spectators. And for the performer, while a white veil may feel the same as a black one, the change in her appearance would be clear as she regarded her fellow 'Marys', newly clothed in white.

Similar re-dressing or re-veiling ceremonies took place prior to Visitatio performances at other convents which, like Barking, also sometimes involved confession to the Abbess, or other purificatory rituals for their female participants. ${ }^{48}$ Such rituals are not (so far as extant evidence shows) prescribed for male Visitatio participants, a fact which might be read as insinuating that women, since their sex was more associated with the sinning body, ${ }^{49}$ require more stringent purification before participating in such a performance. Alternatively, these rituals might constitute an

University Presses, 2002), 145-146 describes the place of the Confiteor or Confession within lay and monastic life and liturgical rite.

${ }^{47}$ Our performance underlined the length of time which this procedure would have taken. We reclothed our three Marys simultaneously (they were partially visible to some parts of the congregation/audience through a grille), giving each a 'dresser' who helped with their surplice and re-veiled them, as the Abbess would have done for each in turn. Even with this time-saving expedient, the re-veiling still rendered our audience uncomfortable because of the silent time it took: contemporary audiences are acculturated to performance as focused towards their experiences as spectators/auditors and are unprepared for spaces of time in which (apparently) 'nothing' is happening, from their perspective.

${ }^{48}$ Ogden, Staging, 145-146 surveys these convents and their purification rituals. The surviving Visitatio Sepulchri ceremonies from women's houses that Ogden lists here all employ nuns as performers of the three Marys only; priests and/or deacons take on other roles, such as that of Christ or the Angels.

${ }^{49}$ For the persistent medieval association of women with the flesh, men with the spirit, and its roots in patristic and medical thought, see Alcuin Blamires, Karen Pratt and C. William Marx, eds., Woman Defamed and Woman Defended (Oxford: Clarendon Press, 1992). 
assertive, carefully constructed and performed rebuttal of such misogynistic attitudes, an authorisation and demonstration of the appropriateness and power of female performance within the Visitatio.

How might the feeling of re-dressing, the touch of the new veil in the hands of the Abbess, have affected a sister? Did it free the sister's body from its inappropriate, feminine connotations and restriction, or did it adorn that body with garments affirming female power and purity, encouraging sisters to think of their bodies, in the moments of performance, as signifying something especially sacred? Possibly, it possessed a more pointedly theatrical significance, encoding a performer's temporary and partial transition from individual nun to scriptural role through tactile perception. The physical sensations produced by re-veiling at the hands of the most powerful woman in the convent, in a location dedicated to a second, powerful Christian woman whose narrative is about to be re-iterated, might form an opportunity for sisters to consider themselves as partially entering a new temporal, spatial and narrative sphere for the duration of the Visitatio, replaying scriptural characters, time and place, and overlaying that time and place onto their contemporary setting. The touch of the Abbess's hands on the head and her imposition of a veil also, of course, recall a far more specific and personal ceremony: that of profession, which all sisters would have undergone. ${ }^{50}$ The re-veiling, then, might additionally have triggered within participants their very individual memories of profession; might, indeed, have been designed to do so. Mary Magdalene, in her love for and physical, tactile devotion to Christ, clearly forms a behavioural model for the sisters whose own profession and veiling took the form of a turning away from the world into a symbolic marriage with Christ. ${ }^{51}$ The narrative events of Easter, re-presented within the Visitatio, see Mary Magdalene and her female companions on the cusp of a radical new phase of their belief and their lives, undergoing a transition from

${ }^{50}$ Alison Findlay, Playing Spaces in Early Women's Drama (Cambridge: Cambridge University Press, 2006), 153, notes this connection. Nancy Bradley Warren, Spiritual Economies: Female Monasticism in Later Medieval England (Philadelphia: University of Pennsylvania Press, 2001), 4-9, 25-29 and 194, no. 126 discusses medieval English Benedictine profession and consecration ceremonies. She underlines the role which the Abbess played in the changing of the novice's clothing and veil as she made her profession (9).

${ }^{51}$ On Mary Magdalene and her impact on medieval devotional culture, see Katherine Ludwig Jansen, The Making of the Magdalene: Preaching and Popular Devotion in the Later Middle Ages (Princeton, NJ: University of Princeton Press, 2001). 
living alongside Jesus in the world to travelling, and spreading the Gospel in the name of the risen Christ: ${ }^{52}$ the re-veiling at the hands of the Abbess, and the memories of a turning point in one's life which that touch could trigger, might conceivably bring a very particular resonance to the ways in which each performer experienced her role.

In asserting this, we are not suggesting an anachronistic sense of female performer 'identifying with' or fully 'becoming' her scriptural counterpart. A fundamental separation, or non-identification, between performer and part designedly characterises medieval understandings of theatrical performance. Medieval players were not attempting to 'become' the roles they embodied: player and part remained distinct in the space and time of performance, and while this is generally true of medieval theatre, it is perhaps most obvious in liturgical plays, if only because they contain unusually detailed descriptions of their action in which this separation is articulated. The episode of the Visitatio Sepulchri is one for which we have abundant evidence. The varying dramatised texts that were prepared for performance in conjunction with the Easter liturgy in both men's and women's religious houses maintain a clear sense of liturgical purpose, indicated particularly in what can loosely be called stage directions relating to space, attire and props: the Wilton 'Angel', for example, is not an angel but 'one priest dressed in a mantle and alb' ('unus sacredos amictu indutus et alba'), who sits at the tomb 'holding a palm in his hand in the likeness of the angel' (manu tentus palmam ... in similitudine angeli); while the Marys carry thuribles not spice jars. ${ }^{53}$ If liturgy is the form that facilitates worship, the reader is constantly reminded of that form-and the liturgical nature of the attire worn and objects used would also be immediately obvious to the spectator.

\footnotetext{
${ }^{52}$ In Middle English Digby Life of St Mary Magdalene play, the commonly known narrative of Mary's life and death forms the subject of secular theatre. Here, the rare Middle English term 'apostylesse', that is, female apostle, is used to describe Mary's role after Christ's Ascension, explicitly aligning her evangelising activity in Marseille-depicted in the playwith that of Christ's male apostles elsewhere. Donald C. Baker, John L. Murphy, and Louis B. Hall, eds., The Late Medieval Religious Plays of Bodleian MSS Digby 133 and e Museo 160 (London and New York: Oxford University Press, 1982), 70, 1. 1381. The Digby play and its socio-cultural resonances are discussed by Theresa Coletti, Mary Magdalene and the Drama of the Saints: Theatre, Gender and Religion in Late Medieval England (Philadelphia: University of Pennsylvania Press, 2004).

${ }^{53}$ Rankin, 'New English Source', 6.
} 
In Wilton Mary is never addressed by Christ, but by the priest-Angel, who declares: 'I am called Jesus... Recognize your God' ('ego sum ihesus vocitur... tuumagnosce deum') before striking her head with a weapon ('spiculo'): when asked what she saw, Mary replies: 'I saw the tomb of the living Christ and the glory of Him risen... I saw the angelic witnesses, the sudarium and His garments' ('Sepulchrum christi viventis et gloriam vidi resurgentis... angelicos testes sudarium et vestes') - pretty much anything, in fact, except Jesus himself. ${ }^{54}$ The same wording is found in the St Lambrecht Visitatio, which specifies that the cloths the Marys find are those that have been wrapped around the cross and the head of the crossnot Christ - in the Good Friday liturgy, but which are nonetheless now signs of Christ's resurrection. ${ }^{55}$ In a particularly striking set of 'stage directions' in the Fleury Visitatio, Mary Magdalene encounters 'one made up in the likeness of a gardener' ('quidam praeparatus in similitudinem hortulani') and this participant then re-costumes himself in elaborate vestments as Christ to address Mary again ('Interea is qui ante fuit hortulanus in similitudinem Domini veniat, dalmaticatus candida dalmatica, candida infula infulatus, phylacteria pretiosa in capite, crucem cum labaro in dextra, textum auro paratum in sinistra habens'), ('Meanwhile let him who earlier was the gardener come in the likeness of the Lord, vested in a white dalmatic, adorned with a white infula, a costly phylacterium on his head, having a cross with a standard in his right hand, a garment woven of gold in his left hand'). ${ }^{56}$ Curiously, the directions seem to make the same mistake as Mary in failing to identify the Gardener with Christ: presumably this is not based on ignorance of the gospel narrative, but perhaps indicates the weight attached to the liturgical vestments that Christ must wear in order to be recognisable. The role is as separable from the performer as his vestments.

Brazil has recently discussed the verbs used in the Barking Abbey Vistiatio to express what each sister does to her role as she takes it on, particularly the verb associated with Mary Salomé: 'Tercia Maria vicem optinens Salomee tercium canat versum' (the third Mary, occupying/possessing/holding the office of Salomé, sings the third verse in turn). ${ }^{57}$ The

\footnotetext{
${ }^{54}$ Rankin, 'New English Source', 10.

${ }^{55}$ Bevington, Drama, 37.

${ }^{56}$ Bevington, Drama, 44.

${ }^{57}$ Young, Drama, I, 381, trans. Aurélie Blanc. Our analysis here is indebted to Brazil's presentation and discussion: Sarah Brazil, 'A Critical Reassessment of Dramatic Terminology;
} 
polysemous Latin verb op/btinere implies the temporary inhabitation of a pre-determined space. ${ }^{58}$ The role of Mary Salomé pre-exists, a stable framework or a place into and out of which a performer moves. ${ }^{59}$ This formulates a role as something almost akin to theatrical attire-an outer layer which the performer temporarily adopts, which touches her from the outside, partially overlaying her but always existing outside her. This conceptual approach to performance might, therefore, be fruitfully aligned with the re-veiling ritual which takes place prior to the Barking Visitatio. We have suggested that the imposition of white veils, the feel of white surplices and the touch of the Abbess's hands might 'cue' sisters to take a mental step backwards in time towards the moment of their own profession, touch functioning as the medium by which this event is brought into the present. These sensations might, simultaneously, form a physical counterpart to the way in which the Visitatio presents performance-asoccupation, the touch of new or different textiles on the head and body reminding sisters of the temporary 'touch' of their scriptural role. Touch requires difference and distance; the role is as distinct from the sister as a costume. And the sister does not touch the role-noli me tangere-but is touched by it, even as Christ's hand, reaching out to stay Mary Magdalene, potentially touches her, too.

Attending to the sensation of touch within medieval convent plays is crucial. The very particular tactile encounters which convent theatre offered to its participants must, we suggest, have had a variety of significant effects upon the practice of faith of enclosed women religious. These encounters could afford a sister new, transformational and perhaps transgressive corporeal experiences: the social performance of a male body; the opportunity to 'step into' a Biblical role and temporarily to occupy it, potentially through a sensory recollection of the moment of her profession (itself a transitional experience functioning at a bodily and a spiritual level);

or, the Problem with 'Mimesis" (paper, Medieval English Theatre Conference, University of Glasgow, UK, March 24-26, 2017).

${ }^{58}$ R. E. Latham, D. R. Howlett, and R. K. Ashdowne, eds., Dictionary of Medieval Latin from British Sources (Oxford: British Academy, 1975-2013), s.v. obtinere, esp. senses 1, 2, 3 and 7 .

${ }^{59}$ Compare Caroline Walker Bynum's discussion of medieval material, artistic representations of saints: "a figure can represent or be "like" a saint-that is, carry his or her power or presence-in the sense that a person... can represent another person... not by looking like but by standing in for' (our emphasis). Christian Materiality: An Essay on Religion in Late Medieval Europe (New York: Zone Books, 2015), 59. 
a prolonged and intimate tactile encounter with a liturgical object, such as a thurible, normally reserved exclusively for the hands of a male priest. Our own experimental staging of the Huy Nativities and the Barking Abbey Visitatio Sepulchri offered evidence of the potential for very different kinds of convent performance to generate some of these experiences in its participants. Our contemporary theatrical work with convent scripts-perhaps particularly the Huy Nativities-also underlined the extent to which sharing these unusual tactile encounters as part of the experiences of performance and preparation for performance enabled the consolidation of social bonds-in this case, through humour. Witnessing our all-female Nativity cast's enthusiastic reaction to Joseph's beard, and the immediate desire to participate in that experience expressed by others playing male roles, emphasised the extent to which convent drama's shared tactile experiences can form the basis of shared emotional responses-in this case, humour sparked in part by the exclusive and transgressive opportunity temporarily to enjoy being a woman explicitly performing a man's body within a convent setting.

The importance of this humour in consolidating social and affective bonds between actresses was emphasised when, after the performances had taken place, we talked to sisters in convents with which we are collaborating. During these conversations, we learned that sisters often perceived community cohesion and effective collaboration to be a result of enclosed theatrical performances. This cohesion, they explained, was fostered through the shared humour and shared joy which arose from all kinds of group theatrical performance, including sisters cross-dressing to play male roles. Our experiences performing and discussing the Huy Nativities remind us that significant sensory experiences, which built and consolidated community bonds, may have taken place during the myriad possible processes of preparation for a performance, as well as during the performance itself. ${ }^{60}$ Some of these preparatory processes, such as the re-veiling of sisters in white, appear to have been codified and recorded or prescribed as a kind of performative precursor or initial element of the Barking Abbey Visitatio. The script of the Huy Nativities, on the other hand, gives no hint of whether or how preparation for their

${ }^{60}$ Cf. Chris Humphrey, The Politics of Carnival: Festive Misrule in Medieval England (Manchester: Manchester University Press, 2001), 5, which reminds us in relation to medieval performative, festive practices that 'what gets recorded... is often just one part of a much larger and more time consuming effort'. 
performance might have taken place, or what impact performance had on the Huy Carmelite community; but this does not indicate that such preparation did not happen, nor that its effects were not felt in important ways.

Analysis which focuses, as we have done here, specifically on the sensory experiences of the performer rather than the spectator is not, of course, an approach appropriate only to convent theatre, although we have suggested that it forms an important framework through which to approach the very particular social and religious work of these plays. A similar focus on the bodily experiences of a performer might facilitate insights into the functioning of touch within performance for medieval players in other contexts. For example, the fifteenth-century clerics (or, indeed, schoolboys) who represented the three Marys at Wells Cathedral must have undergone a physical experience which was very different to that of their peers in other religious institutions, who undertook similar roles in traditional liturgical vestments. Interrogating not just how performers looked, from their spectators' viewpoint, but also how performers felt, particularly their tactile experiences of clothing, props, wigs and beards, offers fresh insight into the effects of performance. The evidence of medieval convent theatre suggests that such effects may have been both profound and multifaceted.

\section{REFERENCES}

\section{Manuscripts ANd Archives}

Arxiu del Monestir de Sant Benet de Montserrat/Fons del Monestir de Santa Clara de Barcelona (AMSBM/MSCB), Sacristy Inventory 1421, vol. 31, núm. 6.

Arxiu del Monestir de Sant Benet de Montserrat/Fons del Monestir de Santa Clara de Barcelona (AMSBM/MSCB), Sacristy Inventory 1437, vol. 31, núm. 8.

Liège, Arch. État, Fonds DBH doc. 386bis.

\section{Primary Sources}

Baker, Donald C., John L. Murphy, and Louis B. Hall, eds. The Late Medieval Religious Plays of Bodleian MSS Digby 133 and e Museo 160. London and New York: Oxford University Press, 1982.

Bevington, David, ed. Medieval Drama. Boston: Houghton Mifflin, 1975.

Cohen, Gustave, ed. Mystères et Moralités du ms. 617 de Chantilly. Paris: Droz, 1920. 
Douglas, Audrey, and Peter Greenfield, eds. Records of Early English Drama (REED): Cumberland/Westmoreland, Gloucestershire. Toronto: University of Toronto Press, 1986.

Stokes, James, ed. Records of Early English Drama (REED): Somerset. Toronto, Buffalo, and London: University of Toronto Press, 1996.

Young, Karl, ed. The Drama of the Medieval Church. 2 vols. Oxford: Clarendon Press, 1933.

\section{Secondary Sources}

Altstatt, Alison. 'Re-membering the Wilton Processional'. Notes 72 (2016): 690-732.

Baert, Barbara. "“An Odour. A Taste. A Touch. Impossible to Describe”. Noli me tangere and the Senses'. In Religion and the Senses in Early Modern Europe, edited by Wietse de Boer and Christine Göttler, 111-151. Leiden: Brill, 2013.

Bieringer, Reimund. 'Noli me tangere and the New Testament: An Exegetical Approach'. In Noli me tangere. Mary Magdalene: One Person, Many Images. Exhibition in the Maurits Sabbe Library, 23 February-30 April 2006, 13-27. Leuven: Maurits Sabbe Library, Faculty of Theology KU Leuven, Peeters, 2006.

Blamires, Alcuin, ed. with Karen Pratt and C. William Marx. Woman Defamed and Woman Defended. Oxford: Clarendon Press, 1992.

Blanc, Aurélie, and Olivia Robinson. 'The Huy Nativity from the Seventeenth to the Twenty-first Century: Translation, Playback and Prayback'. Medieval English Theatre 40 (2018): 66-97.

Bradley Warren, Nancy. Spiritual Economies: Female Monasticism in Later Medieval England. Pennsylvania, PA: University of Pennsylvania Press, 2001.

Brazil, Sarah. 'Forms of Pretence in Pre-modern Drama: From the Visitatio Sepulchri to Hamlet'. European Medieval Drama 20 (2016): 181-201.

_. 'A Critical Reassessment of Dramatic Terminology; or, the Problem with "Mimesis". Paper presented at Medieval English Theatre Conference, University of Glasgow, UK, March 24-26, 2017.

Butterworth, Phillip. Staging Conventions in Medieval English Theatre. Cambridge: Cambridge University Press, 2014.

Cadden, Joan. The Meanings of Sex Difference in the Middle Ages. Cambridge: Cambridge University Press, 1993.

Clark, Robert, and Clare Sponsler. 'Queer Play: The Cultural Work of Crossdressing on the Medieval Stage’. New Literary History 28 (1997): 319-344.

Coletti, Theresa. Mary Magdalene and the Drama of the Saints: Theatre, Gender and Religion in Late Medieval England. Philadelphia: University of Pennsylvania Press, 2004.

Critten, Rory, and Annette Kern-Stähler. 'Smell in the York Corpus Christi Plays'. In The Five Senses in Medieval and Early Modern England, edited by Annette Kern-Stähler, Beatrix Busse, and Wietse de Boer, 239-268. Leiden: Brill, 2016. 
Day, Jo. 'Making Sense of the Past'. In Making Senses of the Past: Toward a Sensory Archaeology, edited by Jo Day, 1-31. Illinois: Southern Illinois Press, 2013.

Findlay, Alison. Playing Spaces in Early Women's Drama. Cambridge: Cambridge University Press, 2006.

Green, Monica H. 'Introduction'. In A Cultural History of the Body in the Medieval Age, edited by Linda Kalof, 1-16. New York and Oxford: Berg, 2010.

Hamilakis, Yannis. 'Afterword: Eleven Theses on the Archaeology of the Senses'. In Making Senses of the Past: Toward a Sensory Archaeology, edited by Jo Day, 409-419. Carbondale, IL: Southern Illinois Press, 2013.

Humphrey, Chris. The Politics of Carnival: Festive Misrule in Medieval England. Manchester: Manchester University Press, 2001.

Jansen, Katherine Ludwig. The Making of the Magdalene: Preaching and Popular Devotion in the Later Middle Ages. Princeton: University of Princeton Press, 2001.

Jornet-Benito, Nùria. 'Un Monestir a la Cruilla: Els Inventaris de Sagristia del Monastir de Sant Antoni i Santa Clara de Barcelona (1389-1461)'. Anuario de Estudios Medievales 44 (2014): 277-308.

—. 'Practices, Objects and Spaces. Some Notes about Liturgy and Paraliturgy at the monastery of S. Antoni i S. Clara of Barcelona'. Paper presented at Lo Spazio nei Monasteri Femminili Medievali, University of Padua, Italy, October 20-21, 2017.

Karim-Cooper, Farah. 'The Sensory Body in Shakespeare's Theatres'. In The Five Senses in Medieval and Early Modern England, edited by Annette Kern-Stähler, Beatrix Busse, and Wietse de Boer, 269-285. Leiden: Brill, 2016.

Latham, Ronald Edward, David R. Howlett, and Richard K. Ashdowne, eds. Dictionary of Medieval Latin from British Sources. Oxford: British Academy, 1975-2013.

McGavin, John J., and Greg Walker. Imagining Spectatorship from the Mysteries to the Shakespearean Stage. Oxford: Oxford University Press, 2016.

McRae, Andrew. Renaissance Drama. London: Berg, 2003.

Normington, Katie. 'Player Transformation: The Role of Clothing and Disguise'. In Medieval Theatre Performance, edited by Phillip Butterworth and Katie Normington, 76-92. Cambridge: D. S. Brewer, 2017.

Ogden, Dunbar H. The Staging of Drama in the Medieval Church. Newark and London: Associated University Presses and University of Delaware Press, 2002.

Rankin, Susan. 'A New English Source of the Visitatio Sepulchri'. Journal of the Plainsong and Mediaeval Music Society 4 (1981): 1-10.

Robinson, Olivia. 'Performance-based Research in the Medieval Convent'. European Medieval Drama 21 (2018 for 2017): 21-41.

Ryan, Salvador. 'Christ the Wounded Lover and Affective Piety in Late Medieval Ireland and Beyond'. In The Materiality of Devotion in Late Medieval Northern Europe, edited by Henning Laugerud, Salvador Ryan, and Laura Katrine Skinnebach, 70-89. Dublin: Four Courts Press, 2016. 
Shepherd, Simon. Theatre, Body and Pleasure. London and New York: Routledge, 2006.

Sponsler, Claire. 'From Archive to Repertoire: The Disguising at Hertford and Performing Practices'. In Medieval Theatre Performance, edited by Phillip Butterworth and Katie Normington, 15-34. Cambridge: D. S. Brewer, 2017.

Twycross, Meg. 'Transvestism in the Mystery Plays'. Medieval English Theatre 5 (1983): 123-180.

Twycross, Meg, and Sarah Carpenter. Masks and Masking in Medieval and Early Tudor England. Aldershot: Ashgate, 2002.

Walker Bynum, Caroline. 'The Body of Christ in the Later Middle Ages: A Reply to Leo Steinberg'. Renaissance Quarterly 39 (1986): 399-439.

- Christian Materiality: An Essay on Religion in Late Medieval Europe. New York: Zone Books, 2015.

\section{WEBSITES}

Encyclopaedia Judaica. Accessed May 29, 2018. http://www.jewishvirtuallibrary. org/witness.

The Medieval Convent Drama Project. Fonds National Suisse Grant no. 100015_165887. Accessed February 16, 2018. http://www.medievalconventdrama.org.

The Medieval Convent Drama Project YouTube Channel. Accessed May 2, 2018. https://www.youtube.com/channel/UCsmeDbNTB0cfarSesmpLQzA.

Open Access This chapter is licensed under the terms of the Creative Commons Attribution 4.0 International License (http://creativecommons.org/licenses/ by $/ 4.0 /$ ), which permits use, sharing, adaptation, distribution and reproduction in any medium or format, as long as you give appropriate credit to the original author(s) and the source, provide a link to the Creative Commons licence and indicate if changes were made.

The images or other third party material in this chapter are included in the chapter's Creative Commons licence, unless indicated otherwise in a credit line to the material. If material is not included in the chapter's Creative Commons licence and your intended use is not permitted by statutory regulation or exceeds the permitted use, you will need to obtain permission directly from the copyright holder.

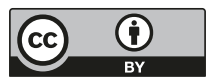

